\title{
A Member of the Closteroviridae from Mint with Similarities to All Three Genera of the Family
}

Ioannis E. Tzanetakis, Department of Botany and Plant Pathology \& Center for Gene Research and Biotechnology, Oregon State University, Corvallis 97331; Joseph D. Postman, National Clonal Germplasm Repository, USDAARS, Corvallis 97333 and Robert R. Martin, Horticultural Crops Research Lab, USDA-ARS, Corvallis 97330

\begin{abstract}
Tzanetakis, I. E., Postman, J. D., and Martin, R. R. 2005. A member of the Closteroviridae from mint with similarities to all three genera of the family. Plant Dis. 89:654-658.

Mentha $\times$ gracilis 'Variegata', described more than 200 years ago, is still being used as an ornamental. The bright vein-banding symptoms that confer the ornamental value to 'Variegata' clones are graft transmissible and can be eliminated after heat therapy and apical meristem culture. This observation led us to investigate the possibility that symptoms are virus-induced. Double-stranded RNA extracted from a 'Variegata' clone was cloned. One of the viruses identified was a member of the Closteroviridae family. This virus, designated Mint vein-banding associated virus, shares sequence similarities with all three genera of the family, making it an important link among the genera of the Closteroviridae. A detection protocol has been developed that readily detects the virus in other mint clones that exhibit vein-banding symptoms.
\end{abstract}

Mint (Mentha sp.) is a member of the family Lamiaceae and consists of about 30 species (5). Mint has been cultivated for thousands of years for the volatile oils that give the plant its unique fragrance, and several species are used in the food and medical industry, while some are grown as ornamentals. Several Mentha clones in the National Clonal Germplasm Repository (NCGR) in Corvallis, OR, exhibit symptoms typical of virus infection. One of the ornamental clones, $M . \times$ gracilis 'Variegata' (NCGR MEN 454.001), was first described in 1798 (17). The clone exhibits dramatic vein-banding symptoms (Fig. 1) that are graft-transmissible and can be eliminated by heat therapy and apical meristem culture. Symptoms become less dramatic during summer months. These observations indicated that symptomatology may be virus-induced. Doublestranded RNA (dsRNA) was extracted and cloned from NCGR clone MEN 454.001. Three viruses were identified in this clone: Strawberry latent ringspot virus (14), Mint virus $X$, a newly described potexvirus (21), and a newly identified virus belonging to the family Closteroviridae, which is described here.

A detection protocol developed for the closterovirus was utilized to screen the

Corresponding author: R. R. Martin

E-mail: martinrr@science.oregonstate.edu

Accepted for publication 22 February 2005.

DOI: 10.1094/PD-89-0654

This article is in the public domain and not copyrightable. It may be freely reprinted with customary crediting of the source. The American Phytopathological Society, 2005. mint collection at the NCGR in Corvallis as well as mint clones from nurseries around the United States. During this process, other clones exhibiting mild veinbanding symptoms were found to be infected with the closterovirus, which was thus designated Mint vein-banding associated virus (MVBaV). The nucleotide sequence of more than 8 kilobases has been obtained, including the helicase domain of the replicase, the polymerase, heat shock protein 70 homolog, coat protein homolog, one of the coat protein genes, and two putative genes of unknown function. Sequence and phylogenetic analysis indicated that $\mathrm{MVBaV}$ shares characteristics of all three genera of the family, making it a candidate as a progenitor for the family Closteroviridae.

\section{MATERIALS AND METHODS}

Virus transmission. Since virus purification from mint yielded few virus particles as judged by transmission electron microscopy, attempts were made to transmit the virus to other herbaceous plants. Eight plant species (Chenopodium quinoa, C. amaranticolor, Cucumis sativus, Glycine max, Nicotiana benthamiana, N. occidentalis, N. tabacum, and Tetragonia tetragonioides), as well as virus-free clones of NCGR MEN 454.001 (NCGR MEN 454.002) that became asymptomatic after heat treatment and apical meristem culture, were inoculated with infected tissue from clone NCGR MEN 454.001. Carborundum (660 mesh) dusted leaves of five plants of each of the herbaceous species and 30 plants of NCGR MEN 454.002 were inoculated using leaf tissue from symptomatic mint homogenized in $0.05 \mathrm{M}$ phosphate buffered saline (PBS), $\mathrm{pH}$ 7.4, containing $2 \%$ nicotine, at a wt/vol ratio of 1:10.

Mint aphids (Ovatus crataegarius), obtained from a plant that tested negative for $\mathrm{MVBaV}$ in a commercial mint field near Corvallis, were given at least a 72-h acquisition access period on MEN 454.001 or a second 'Variegata' clone from Ohio. About 10 aphids from each accession were transferred onto NCGR MEN 454.002 plants. After an inoculation access period of $72 \mathrm{~h}$, the plants were treated with Marathon, a systemic insecticide. Two trials for a total of 20 plants and a trial of 10 plants were inoculated using aphids that had fed on the NCGR MEN 454.001 and the Ohio clone, respectively. All plants were tested for the presence of MVBaV 1 month after the application of insecticide.

DsRNA extraction and virus purification. DsRNA extraction was carried out as described previously (18). Virus purification was performed according to the method of Martin and Bristow (10). The virions were visualized after negative staining of the virus preparation with $2 \%$ ammonium molybdate.

cDNA synthesis, cloning, and sequence analysis. cDNA synthesis using NCGR MEN 454.001 dsRNA templates was performed with the method of Tzanetakis et al. (19). Briefly, dried dsRNA from $4 \mathrm{~g}$ of tissue was denatured for $30 \mathrm{~min}$ at room temperature in a mixture of $1 \mu \mathrm{g}$ of random hexameric nucleotide primers and $20 \mathrm{mM}$ methyl mercuric
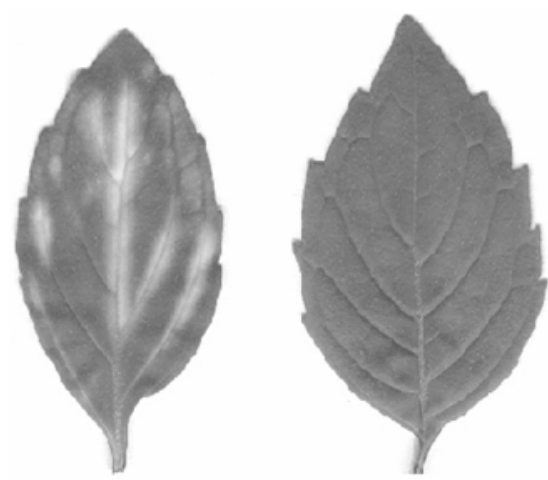

Fig. 1. Typical Mentha $\times$ gracilis 'Variegata' symptoms. Left: leaf from the 'Variegata' MEN 454.001 showing vein-banding symptoms used in cloning. Right: leaf of clone MEN 454.002, derived from MEN 454.001 by thermal therapy and meristem tip culture and free of Mint veinbanding associated virus. 
hydroxide in a volume of $7 \mu$ l. Reverse transcription mix consisting of $50 \mathrm{mM}$ Tris acetate $(\mathrm{pH} 8.4), 75 \mathrm{mM}$ potassium acetate, $8 \mathrm{mM}$ magnesium acetate, $20 \mathrm{mM}$ DTT, $0.4 \mathrm{mM}$ deoxynucleotides (dNTPs), and 200 U Superscript III reverse transcriptase (Invitrogen, Carlsbad, CA) was added to a final volume of $50 \mu \mathrm{l}$. After brief incubation at room temperature for 2 min, the reaction was carried out at $50^{\circ} \mathrm{C}$ for $60 \mathrm{~min}$. Second-strand synthesis was performed in the same tube after addition of 2 units of RNase $\mathrm{H}$ (Invitrogen) and a mixture of AatII, EcoNI, HpaI, and NcoI restriction endonucleases (20 $\mathrm{U}$ each). The reaction was then incubated for another 60 $\min$ at $37^{\circ} \mathrm{C}$. DNA was then purified from the reaction utilizing the polymerase chain reaction (PCR) purification system (Marligen Biosciences, Ijamsville, MD) and eluted in $50 \mu \mathrm{l}$ of water. Taq polymerase (New England Biolabs, Beverly, MA) (2.5 units), the buffer provided by the manufacturer, and $0.2 \mathrm{mM}$ dNTPs were added and the reaction was incubated for $30 \mathrm{~min}$ at $75^{\circ} \mathrm{C}$. The cDNA fragments were purified as described above, eluted in $20 \mu$ l of water, and $4 \mu \mathrm{l}$ were used for cloning into the pCR 4.0 TOPO (Invitrogen) vector according to manufacturer's instructions. The sequence presented here was obtained essentially as described previously (20), using primers developed from sequences obtained from the shotgun cloning and PCR to fill in gaps utilizing Takara LA polymerase (Takara MirusBio, Madison, WI).

Detection. RNA was extracted as described previously (18) from $100 \mathrm{mg}$ of tissue. Two sets of primers were utilized for detection of the virus, Pol F (5' ACTAGAGATCCTTCGGCACTCAAGC 3') and Pol R (5' TTATAAGCGAATCCTGCGACTTATC $3^{\prime}$ ) that amplified a 382 base pair (bp) fragment of the polymerase gene and CP F (5' AATTGTATGGCAGGAAGTGAA $3^{\prime}$ ) and CP R (5' GTCTGAATGACGTTGACTTCTT $3^{\prime}$ ) that amplified 318 bases of the coat protein gene. Reverse transcription was carried out as described previously (18) utilizing Superscript III (Invitrogen). PCR was performed utilizing Taq polymerase (NEB Biolabs, Beverly, MA) according to manufacturer's recommendations, in which part of the RT reaction, $10 \%$ of the final volume, served as template. The reactions consisted of 20 $\mathrm{mM}$ Tris- $\mathrm{HCl}$ ( $\mathrm{pH} 8.8$ ), $10 \mathrm{mM} \mathrm{KCl}, 10$ $\mathrm{mM}\left(\mathrm{NH}_{4}\right)_{2} \mathrm{SO}_{4}, 2 \mathrm{mM} \mathrm{MgSO}{ }_{4}, 0.1 \%$ Triton $\mathrm{X}-100,0.5 \mu \mathrm{M}$ of the virus-specific primers, and $0.2 \mathrm{mM}$ dNTPs. The PCR program was initiated with a 5-min denaturation at $95^{\circ} \mathrm{C}$, followed by 40 cycles of 30 $\mathrm{s}$ at $94^{\circ} \mathrm{C}, 30 \mathrm{~s}$ at $55^{\circ} \mathrm{C}$, and $30 \mathrm{~s}$ at $75^{\circ} \mathrm{C}$. The program concluded with an extension step of $10 \mathrm{~min}$ at $75^{\circ} \mathrm{C}$. The reaction products were separated by electrophoresis through a $2 \%$ agarose gel containing 100 $\mathrm{ng} / \mathrm{ml}$ of ethidium bromide and visualized under UV light (Fig. 2). More than 10 amplification products were sequenced to verify the specificity of the products, and all were nearly identical to the original sequence obtained for MVBaV. Several plants from the NCGR collection and 'Variegata' plants from Maryland, Michigan, Nebraska, Ohio, and Oregon were tested for the presence of MVBaV.

Sequence and phylogenetic analysis. Sequences obtained by shotgun cloning were compared with sequences found in GenBank using BLAST (2) to identify $\mathrm{MVBaV}$ sequences. The consensus of the sequence presented was obtained with ClustalW (16). Comparisons of the closterovirus proteins were performed on BLAST (2) (helicase, polymerase) and MatGat (3) (HSP70h). Analysis of the transmembrane motifs was performed on the CBS Prediction Servers (9). PAUP* 4 ver. 10 (15) was utilized for phylogenetic analysis. Maximum parsimony with heuristic search using the tree bisection reconnection swapping algorithm was chosen for the reconstruction of the phylograms. Bootstrap analysis consisted of 1,000 pseudoreplications.

\section{RESULTS}

Virus transmission. The NCGR MEN 454.002 clone was tested for the presence
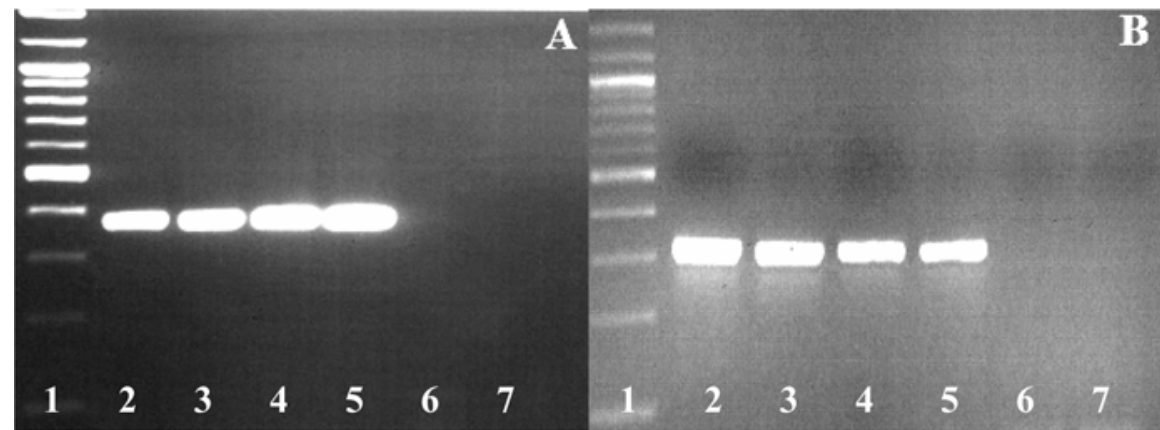

Fig. 2. Detection of Mint vein-banding associated virus. Ethidium bromide stained agarose gels with reverse transcription polymerase chain reaction products of $\mathbf{A}$, polymerase and $\mathbf{B}$, coat protein. Lane 1 : 100-bp DNA ladder (BRL, Gaithersburg, MD); lanes 2 to 5: 'Variegata' NCGR 454.001, 'Variegata' from Ohio, M. canadensis (NCGR MEN 617), and M. spicata clones, respectively, infected with Mint vein-banding associated virus; lane 6: 'Variegata' clone from Maryland; and lane 7: Heat-treated 'Variegata' used as negative control.

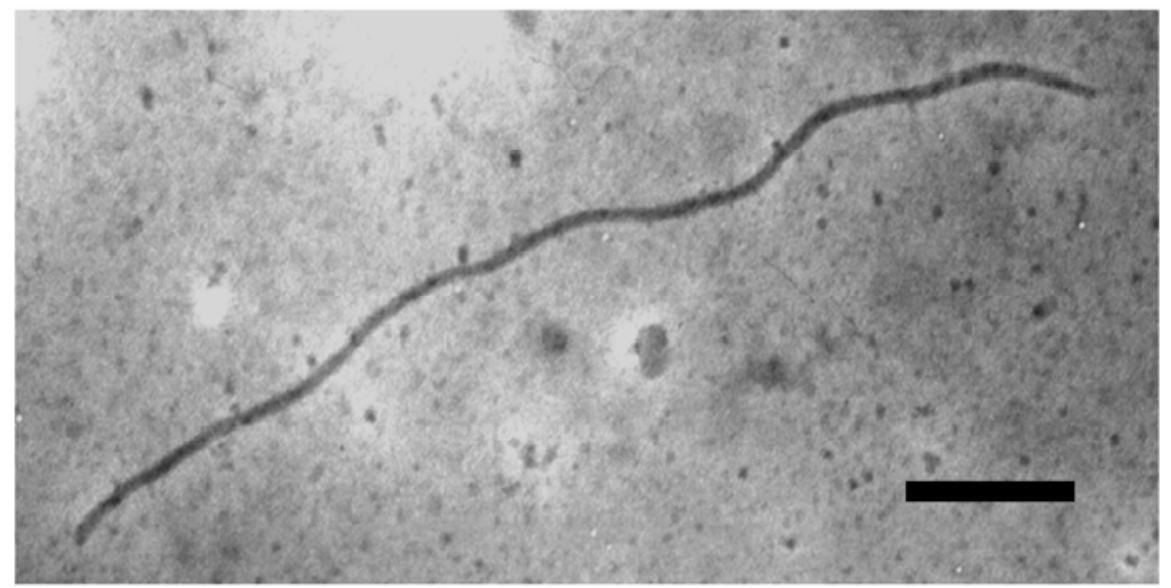

Fig. 3. Electron micrograph of a negatively stained virion of Mint vein-banding associated virus. Bar = $200 \mathrm{~nm}$.

of all three viruses by dsRNA isolation and reverse transcription-polymerase chain to be virus-free prior to its use in the aphid transmission studies. All indicator plants tested negative by RT-PCR for the presence of the virus 1 month after mealeven of $20 \mathrm{~min}$ MEN 454.001 isolate and four of 10 plants inoculated with the Ohio isolate tested positive for the virus by RT-PCR. All 15 plants infected with MVBaV after
aphid transmission remained asymptomatic for a period of 6 months after aphid transmission. Several of the PCR products from the transmission studies were sequenced and confirmed that the sequences.

Virus purification and dsRNA extraction. Virus purification, performed twice, yielded a minimal amount of virions. Long filamentous virions of about $1,500 \times 12$
$\mathrm{~nm}(n=5)$ were observed (Fig. 3). DsRNA was extracted from three plants used in the aphid transmission study, and detection for all three viruses found in NCGR 454.001 was performed in these plants yielding amplicons only for MVBaV. The dsRNA

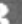

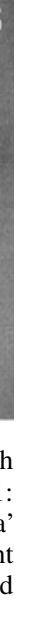
. 


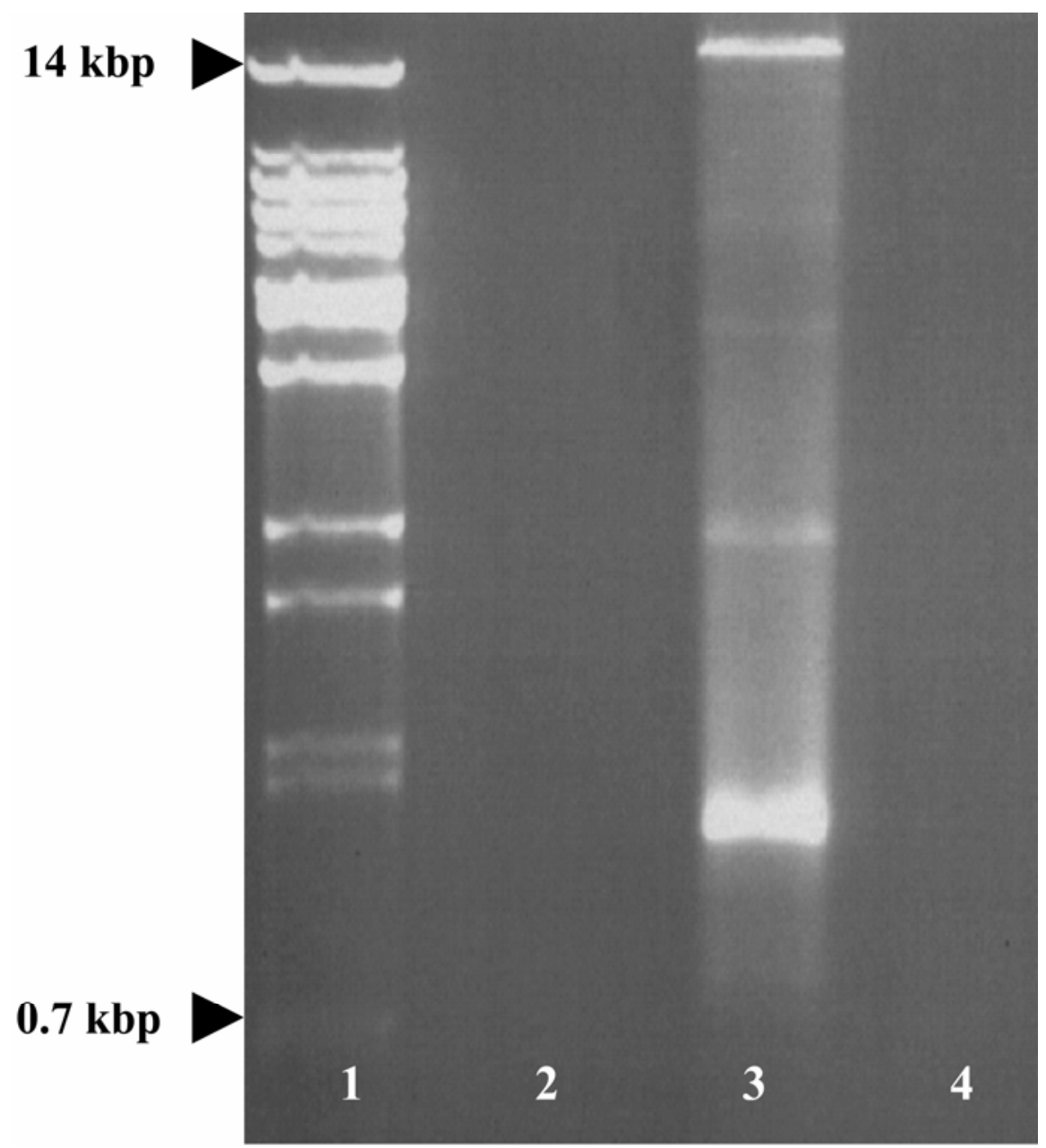

Fig. 4. Double-stranded RNA (dsRNA) extracted from mint plants infected with Mint vein-banding associated virus. Lane 1: $\lambda$-BsteII DNA marker (BRL, Gaithersburg, MD); lane 2: blank; lane 3: dsRNA extracted from mint plant infected with Mint vein-banding associated virus after aphid transmission; lane 4: dsRNA extracted from heat-treated 'Variegata' clone.

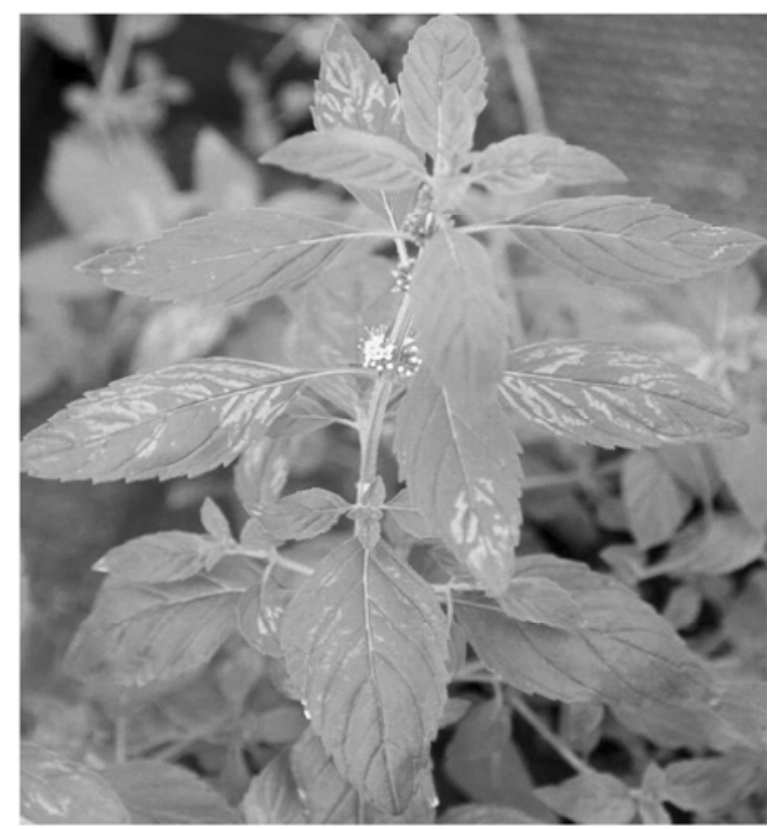

Fig. 5. Mentha canadensis infected with Mint vein-banding associated virus showing vein-banding symptoms. pattern extracted from one of these plants is shown in Figure 4.

Detection. Of the plants showing yellow vein-banding symptoms, typical of 'Variegata' plants, the Maryland, Michigan, and Nebraska clones tested negative for the virus, and only NCGR MEN 454.001 and the clone from Ohio were infected with MVBaV. Four other plants representing other Mentha species, one M. canadensis (Fig. 5), one M. spicata, and two $M . \times$ piperita clones that showed yellow vein-banding symptoms were also infected with MVBaV but not the other two viruses found in MEN 454.001. These plants were tested with both sets of primers used for detection, and all amplicons were sequenced to verify the results.

Sequence analysis. More than eight kilobases of nucleotide sequence of MVBaV (GenBank Accession No. AY548173) were acquired by a combination of the shotgun cloning and RT-PCR. The 5' proximal region contained the helicase signature motifs of the virus and was 264 amino acid (aa) residues long (4). The region shows over $35 \%$ aa sequence identity and $49 \%$ similarity with the most closely related species of each genus of the family (Table $1)$. The viral polymerase is probably expressed by a +1 ribosomal frameshift as is the case with other members of the family $(1,6)$. The putative polymerase contains 520 aa and has a mass of $59 \mathrm{kDa}$ containing the eight conserved motifs of RNA dependent RNA polymerases between residues 189 and 427 (8). The similarities and identities of the polymerase conserved motifs region of $\mathrm{MVBaV}$ with the most closely related members of the three genera of the Closteroviridae is shown in Table 1. A small hydrophobic protein of 6 $\mathrm{kDa}$ whose homologous gene in Beet yellows virus is involved in virus movement (13) follows the polymerase gene. A transmembrane helix of this protein is predicted between aa 15 and 32 (8). Six nucleotides after the stop codon of the small hydrophobic movement protein is the start codon of the trademark gene of the family, the heat shock 70 homolog protein (HSP70h), a gene also involved in virus movement (12). MVBaV HSP70h is 566 aa long and has a predicted mass of $63 \mathrm{kDa}$. The homology with other closterovirus orthologs is shown in Table 1. An open reading frame (ORF) newly identified as a coat protein homolog $(\mathrm{CPh})(11)$ is found downstream of the HSP70h gene. Orthologous genes are found after the HSP70h of other closteroviruses, and the protein is involved in virus movement and virion assembly (11). The ORF is 527 aa long with predicted mass of $62 \mathrm{kDa}$. A coat protein gene that codes for a $25 \mathrm{kDa}$ protein (231 aa long) follows the $\mathrm{CPh}$ ORF. The $\mathrm{CP}$ protein shows homology with both types of coat protein genes of other members of the 
family, and thus it could be either the major or minor coat protein of the virus. The putative coat protein gene is followed by an ORF encoding for a putative 15 $\mathrm{kDa}$ protein with no significant homology to any other protein in the database. The final ORF presented in this communication is a putative protein of 204 aa and 24 $\mathrm{kDa}$, without significant homology to viral proteins.

\section{DISCUSSION}

A new member of the family Closteroviridae, infecting mint, Mint vein-banding associated virus, is presented in this communication. The sequence information presented, the comparison of three conserved regions of the genomes of members of each of the three Closteroviridae genera and MVBaV (Table 1), and the phylogenetic analysis based on the conserved mo-

Table 1. Amino acid sequence identity and similarity (in parentheses) of the Mint vein-banding associated virus helicase and polymerase conserved motifs and the heat shock protein 70 homolog (HSP70h) for the most closely related members of the three genera of the Closteroviridae ${ }^{\mathrm{a}}$

\begin{tabular}{lccc}
\hline & \multicolumn{3}{c}{ Virus name, amino acid identity (similarity) } \\
\cline { 2 - 4 } Region & Closterovirus & Ampelovirus & Crinivirus \\
\hline Helicase & MV-1, 35 (52) & GLRaV-3, 37 (49) & BYVaV, 36 (51) \\
Polymerase & GRSLaV, 43 (61) & LChV-2, 40 (60) & CYSDV, 43 (61) \\
HSP70h & MV-1, 30 (50) & GLRaV-1, 32 (51) & SPaV, 31 (52) \\
\hline
\end{tabular}

a Abbreviations: BYVaV, Blackberry yellow vein associated virus; CYSDV, Cucurbit yellow stunting disorder virus; GLRaV-1, Grapevine leafroll associated virus-1, AAF22740; GLRaV-3, Grapevine leafroll associated virus-3; GRSLaV, Grapevine rootstock stem lesion associated virus; LChV-2, Little cherry virus-2; MV-1, Mint virus-1; SPaV, Strawberry pallidosis associated virus. All sequences were acquired from the GenBank accessions of the complete genome of the viruses except GLRaV-1, where accession is given.

tifs of the polymerase and the HSP70h gene (Fig. 6) indicate that MVBaV shares characteristics with all three genera of the family, placing the virus at the center of the family as known today. While there are another two members of the family, Little cherry virus-1 and Grapevine leafroll associated virus-7, that are not assigned to any genus of the family, sequence analysis reveals that both viruses share similarities with members of the Crinivirus genus rather than the other two genera, unlike the case with MVBaV. There are two possible explanations for the origin of MVBaV. The virus may be an ancestral member of the family, a virus that emerged before the division of the family into the three genera, or alternatively, it may be a product of multiple recombinations between members of the three genera. Transmission studies indicated that the virus is transmitted by the mint aphid, which may provide an insight into the mode of transmission of the progenitor of the family. The virus is presumed to be monopartite, because particle length is longer than virions of the
A

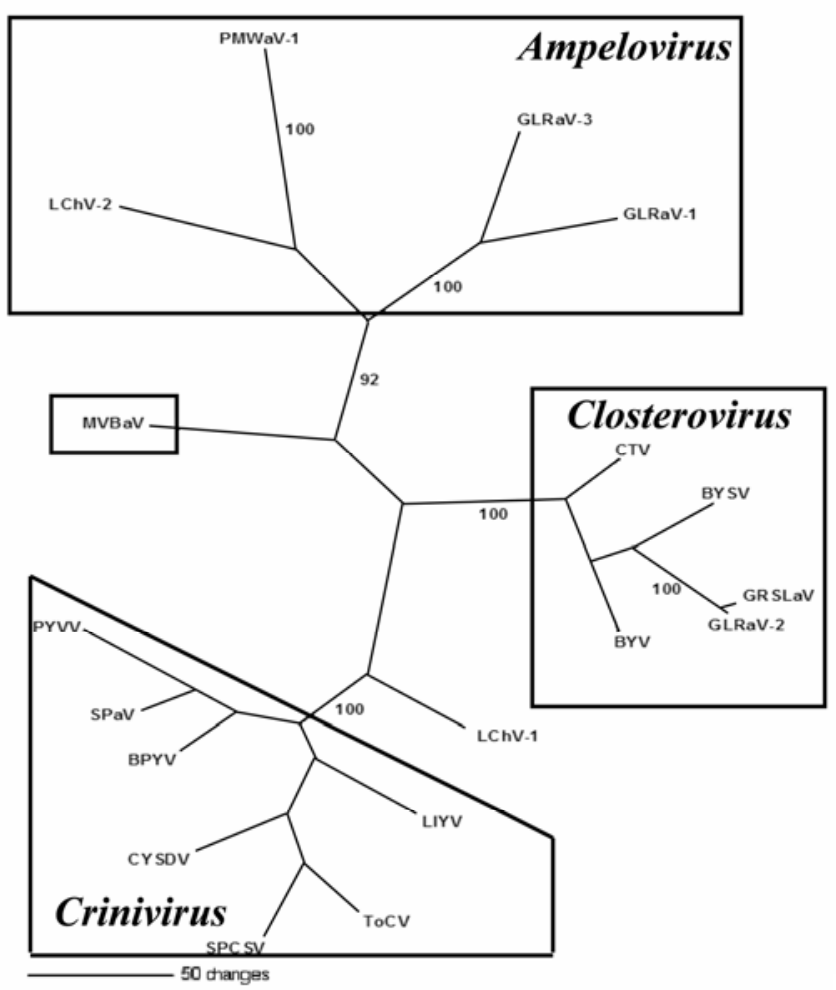

B

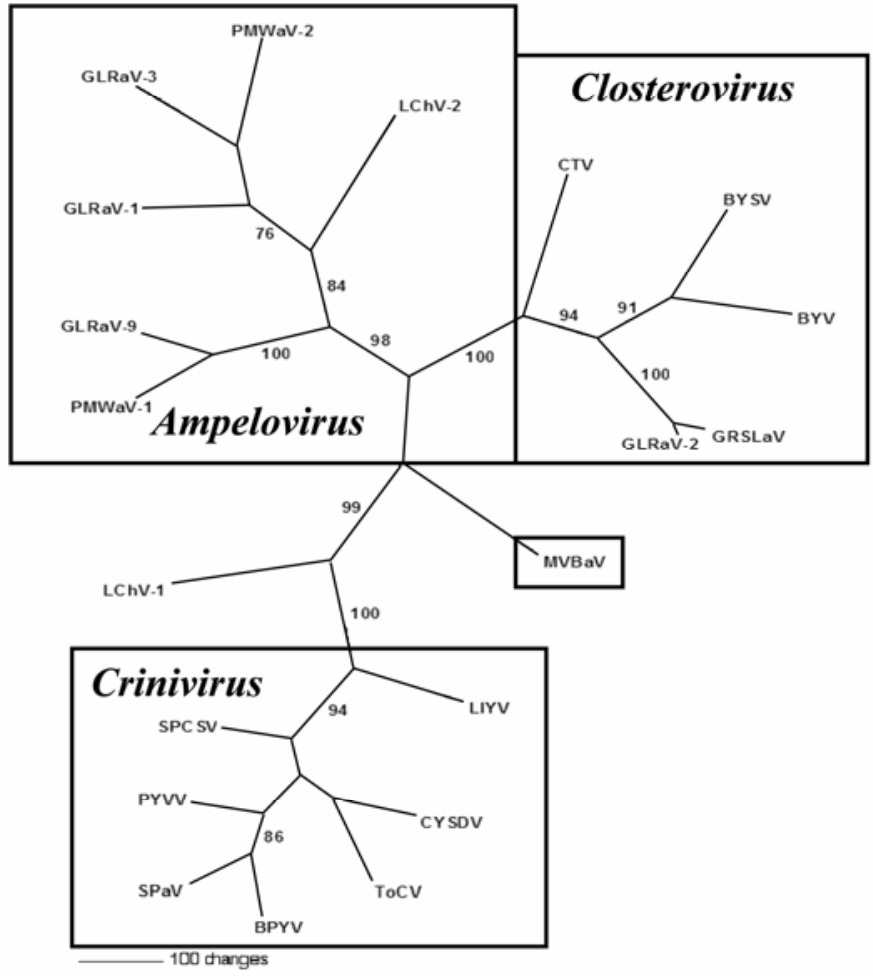

Fig. 6. A, Phylogram of the conserved polymerase motifs of Mint vein-banding associated virus (MVBaV) and members of the Closteroviridae. Abbreviations and GenBank accession numbers: MVBaV, AAS57939; CTV, Citrus tristeza virus, NP733947; BYSV, Beet yellow stunt virus, AAC55659; BYV, Beet yellows virus, NP733949; GRSLaV, Grapevine rootstock stem lesion associated virus, NP835244; GLRaV-2, Grapevine leafroll associated virus-2, AAC40856; LChV-2, Little cherry virus-2, AAP87784; PMWaV-1, Pineapple mealybug wilt-associated virus-1 AAL66709; GLRaV-1, AAF22738; GLRaV-3, AAC40705; SPaV, Strawberry pallidosis associated virus, AY488137; BPYV, Beet pseudo-yellows virus, NP940796; PYVV, Potato yellow vein virus, CAD89680; CYSDV, Cucurbit yellow stunting disorder virus, AAM73639; ToCV, Tomato chlorosis virus, (W. M. Wintermantel, personal communication); SPCSV, Sweet potato chlorotic stunt virus, NP733939; LIYV, Lettuce infectious yellows virus, AAA61798; LChV-1, NP733945. Bootstrap values are shown as percent value, and only nodes over $70 \%$ are labeled. Bar represents 50 amino acid changes over the length of the proteins. B, Phylogram of heat shock protein 70 homolog of MVBaV and members of the Closteroviridae. GenBank accession numbers: MVBaV, AAS57941; CTV, NP042864; BYSV, AAC55662; BYV, NP041872; GRSLaV, NP835247, GLRaV-2, AAR21242; LChV-2, AF531505; PMWaV-1, AAL66711; PMWaV-2, AAG13941; GLRaV-1, AAK38612; GLRaV-3, NP813799; GLRaV-9, AAL68401; SPaV, AAO92347; BPYV, AAQ97386; PYVV, CAD89682; CYSDV, NP851572; ToCV, AF024630; SPCSV, NP689401; LIYV, NP619695; LChV-1, NP045004. Bootstrap values are shown as percent value, and only nodes over 70\% are labeled. Bar represents 100 amino acid changes over the length of the proteins. 
Crinivirus genus, and because the sequence data presented span the genome region that would normally represent part of RNA 1 and RNA 2 of the criniviruses. In addition, the dsRNA pattern seen in Figure 4 indicates that the genome exceeds $14 \mathrm{~kb}$, the size of the genome reported in ampelo- or closteroviruses.

The sequence diversity within closterovirus species is well established ( 7 and references within). In order to minimize the possibility of false negatives in RTPCR detection, two sets of detection primers were developed. All plants that tested positive for $\mathrm{MVBaV}$ with one primer set also tested positive with the second set when such a PCR reaction was performed. This may be an indication that these plants were infected with closely related isolates, or alternatively that $\mathrm{MVBaV}$ does not show the extreme sequence diversity of other closteroviruses. The latter would argue against the hypothesis that the virus is a progenitor of the family Closteroviridae.

MVBaV was not found in all 'Variegata' clones tested, an indication that the virus is not the causal agent of the symptomatology. The positive plants in the aphid transmission studies were also asymptomatic. While MVBaV causes no visual symptoms on $M . \times$ gracilis, it appears to cause vein-banding symptoms in other mint species. The effects of the virus on plant vigor and oil production remain to be determined.

The detection tools developed will be utilized in a survey in the major mint producing areas of the United States to determine how widespread the virus is in both commercial fields and nurseries. Preliminary results have verified the presence of the virus in Oregon and Colorado (I. E. Tzanetakis, unpublished data).

\section{ACKNOWLEDGMENTS}

We thank Dr. Wintermantel (USDA, Salinas, CA) for providing the polymerase sequence of Tomato chlorosis virus for phylogenetic analysis prior to publication and Dr. Michael Nesson for his help with the electron microscope. This project was partially funded by the Mint Industry Research Council.

\section{LITERATURE CITED}

1. Agranovsky, A. A., Koonin, E. V., Boyko, V. P., Maiss, E., Frotschl, R., Lunina, N. A., and Atabekov, J. G. 1994. Beet yellows closterovirus: Complete genome structure and identification of a leader papain-like thiol protease. Virology 198:311-324.

2. Altschul, S. F., Madden, T. L., Schäffer, A. A., Zhang, J., Zhang, Z., Miller, W., and Lipman, D. J. 1997. Gapped BLAST and PSI-BLAST: A new generation of protein database search programs. Nucleic Acids Res. 25:3389-3402.

3. Campanella, J. J., Bitincka, L., and Smalley, J. 2003. MatGAT: An application that generates similarity/identity matrices using protein or DNA sequences. BMC Bioinformatics 4:\#29, 4 pp.

4. Candresse, T., Morch, M. D., and Dunez, J. 1990. Multiple alignment and hierarchical clustering of conserved amino acid sequences in the replication associated proteins of plant RNA viruses. Res. Virol. 141:315-329.

5. Dorman, H. J., Kosar, M., Kahlos, K., Holm, Y., and Hiltunen, R. 2003. Antioxidant properties and composition of aqueous extracts from Mentha species, hybrids, varieties, and cultivars. J. Agric. Food Chem. 51:4563-4569.

6. Jelkmann, W., Fechtner, B., and Agranovsky, A. A. 1997. Complete genome structure and phylogenetic analysis of little cherry virus, a mealybug-transmissible Closterovirus. J. Gen. Virol. 78:2067-2071.

7. Karasev, A. V. 2000. Genetic diversity and evolution of closteroviruses. Annu. Rev. Phytopathol. 38:293-324.

8. Koonin, E. V. 1991. The phylogeny of RNAdependent RNA polymerases of positive-strand RNA viruses. J. Gen. Virol. 72:2197-2206.

9. Krogh, A., Larsson, B., von Heijne, B., and Sonnhammer, E. L. L. 2001. Predicting transmembrane protein topology with a hidden Markov model: Application to complete genomes. J. Mol. Biol. 305:567-580.

10. Martin, R. R., and Bristow, P. R. 1988. A carlavirus associated with blueberry scorch disease. Phytopathology 78:1636-1640.

11. Napuli, A. J., Alzhanova, D. V., Doneanu, C. E., Barofsky, D. F., Koonin, E. V., and Dolja, V. V. 2003. The 64-kilodalton capsid protein homolog of Beet yellows virus is required for assembly of virion tails. J. Virol. 77:23772384.

12. Peremyslov, V. V., Hagiwara, Y., and Dolja, V. V. 1999. HSP70 homolog functions in cell-tocell movement of a plant virus. Proc. Natl. Acad. Sci. 96:14771-14776.

13. Peremyslov, V. V., Pan, Y. W., and Dolja, V. V. 2004. Movement protein of a closterovirus is a type III integral transmembrane protein localized to the endoplasmic reticulum. J. Virol. 78:3704-3709.

14. Postman, J. D., Tzanetakis, I. E., and Martin, R. R. 2004. First report of Strawberry latent ringspot virus in a Mentha sp. from North America. Plant Dis. 88:907.

15. Swofford, D. L. 2001 PAUP*: Phylogenetic analysis using parsimony (*and Other Methods). Version 10. Sinauer Associates, Sunderland, MA.

16. Thompson, J. D., Higgins D. G., and Gibson, T. J. 1994. CLUSTALW: Improving the sensitivity of progressive multiple sequence alignment through sequence weighting, positionspecific gap penalties and weight matrix choice. Nucleic Acids Res. 22:4673-4680.

17. Tucker, A. O., and Fairbrothers, D. E. 1972. Mentha $\times$ gentilis L. 'Variegata': Nomenclature and viral origin. Taxon 21:209-210.

18. Tzanetakis, I. E., Halgren, A. B., Keller, K. E., Hokanson, S. C., Maas, J. L., McCarthy, P. L., and Martin, R. R. 2004. Identification and detection of a virus associated with strawberry pallidosis disease. Plant Dis. 88:383-390.

19. Tzanetakis, I. E., Keller, K. E., and Martin, R. R. 2005. The use of reverse transcriptase for efficient first and second strand cDNA synthesis from dsRNA templates. J. Virol. Methods 124:73-77.

20. Tzanetakis, I. E., Mackey I. C., and Martin, R. R. 2004. Strawberry necrotic shock virus is a distinct virus and not a strain of Tobacco streak virus. Arch. Virol. 149:2001-2011.

21. Tzanetakis, I. E., Postman, J. D., and Martin, R. R. 2004. Identification, detection and phylogenetic analysis of new viruses infecting mint. Phytopathology 94:S104. 